\title{
An Analysis on Female Student's Motivation in Comprehending Narrative Text
}

\author{
Shelly Septiani \\ Universitas Islam Negeri Sultan Syarif Kasim Riau, Indonesia \\ shellyseptianiaguan@gmail.com \\ Jasno Susanto \\ Universitas Islam Negeri Sultan Syarif Kasim Riau, Indonesia \\ jasno@uin-suska.ac.id
}

\begin{abstract}
The Purpose of this study is to know how big is the female students' motivation in comprehending narrative text at the first year of State Vocational High School 1 Pekanbaru. From 107 students of the total population which consisted of three classes, the researcher took 33 students as the sample by using purposive sampling technique. In collecting the data, the researcher distributed questionnaire to the respondents to measure their reading motivation in reading comprehension of narrative text. The questionnaire was based on the eleventh indicators of reading motivation which adapted from Motivation for Reading Questionnaire (MRQ) by Watkins and Coffey and combined with narrative components by Suwardati.in analyzing the data, the questionnaire was assessed by rating scale. The result of this research showed that the female students' motivation in comprehending narrative text was $66,2 \%$, and it was categorized into high level of motivation. Based on the research finding, it could be concluded that the female students have high motivation in reading comprehension of narrative text.
\end{abstract}

Keywords : Motivation in Comprehending Narrative Text, Analysis

\section{Introduction}

In learning English, motivation is one of the factors which influence learning process and students' achievement. Motivation is someone's willingness and effort to do something in order to catch what they expect to achieve. Motivation will lead students to do something in learning process. Motivation is also one of the key 
requirements in reaching a good achievement, because motivation will support students' pretension, and it is an important contribution factor in language learning. It is because in learning process, students will learn efficiently and effectively when they have motivation for learning.

Motivation influences all aspects in language learning. One of the aspects is reading. Reading is important. Reading requires understanding and comprehending the means of written words. In other words, reading will require students to interpret, understand, and comprehend the text. Success and failure in reading comprehension activity seems largely depends on students' motivation. Motivation influences students to read and comprehend the text. In particular, students' motivation is important in the development of students' comprehension in reading subject. Motivation will make the students be aware about the importance of reading comprehension.

This research was conducted at the tenth grade female students in Office Management Major of State Vocational High School (SMKN) 1 Pekanbaru. This school uses School Based Curriculum of 2013 (K-13) as a guidance in teaching and learning process. English subject is taught twice a week with the time allocation $2 \times 45$ minutes per meeting. The basic competence that should be achieved in Reading comprehension skill for the tenth grade students is: "Students should be able to comprehend Narrative text in the form of legend short story"
(Kementrian Pendidikan dan Kebudayaan, 2013, p. 68). Based on the basic competence above, it clearly shows that students should e able to read and comprehend Narrative text and they should have motivation in reading in order to make them can get a good comprehension of what they read.

Based on the preliminary research and interview by the researcher to the English teachers at State Vocational High School 1 Pekanbaru about students motivation in reading comprehension that the researcher did on February $2^{\text {th }} 2017$, she found that from 107 female students at the tenth grade in Office Management Major, about $25 \%$ female students are categorized into high motivation, 55\% female students are categorized into low motivation, and $20 \%$ female students are categorized into very low motivation. The students could not reach the standard criteria of minimum achievement (CMA) for the basic competence in reading comprehension of narrative text. The result of the preliminary research and interview was there are some problems have found, such as some of the female students were not able to comprehend the narrative text; some of the female students have lack of motivation in reading comprehension of narrative text because they thought that comprehension is a terrible process for them; some of the female students knew they have lack of motivation in reading comprehension, but they did not try to find the best way to increase their motivation; some of the female students were often come late in English class; 
some of the female students feel bored and lazy in reading activity; some of the female students were seldom in giving responses in learning process; and some of the female students assumed that English subject is only for pass the exam and they did not think English is useful for their future. Based on School Based Curriculum 2013 (2013, p. 68), the criteria of students' reading comprehension skill to achieve the passed-score standard are: the ability of the students to read and comprehend Narrative text in the form of legend short story. It means that students should be able to get the idea of what they read related to the Narrative text.

Most of the students could not reach the standard criteria of minimum achievement and their motivation in reading comprehension was far from the expectation of the curriculum. One of the factors is students' motivation in learning English. Students' motivation in Reading comprehension plays an important role for students' Reading comprehension skill. In other words, it can be said that success and failure in language learning especially in Reading seems highly depends on students' motivation in reading. Regarding with the above idea, Gadner and Lambert (2003 cited in Amelia, 2016, p. 155) stated that motivation is a consistently strong predictor of successful language learning, and it plays important role in language learning.

In language learning, female students have high motivation in reading because they are more oriented to mastery goals and have high intrinsic motivation in learning a language. It was proved by Lau's research, his research finding showed that female students are more oriented to mastery goals and have higher intrinsic motivation in learning. Moreover, Scholes (2010 cited in Mead, 2012, p. 11) stated that female students are more motivated in reading than male students.

Erman (2013, p. 9) also considers that motivation in reading defines as factors that lead and drive students' behavior or desire to read. It means that motivation will make the students have a desire to read. Motivation is a process not a product. It is because motivation will drive someone to do something. In reading comprehension activity, the aim is to comprehend what the students read. According to Sardiman (2007, p. 43) stated that comprehension cannot be separated from one of the psychology elements, that is motivation. Motivation in reading comprehension is a crucial thing for the students, because it makes students comprehend the text. It is also a forcing cause of many activities in reading comprehension activity. It is because motivation will force them to comprehend what they read in reading comprehension activity. Motivation will also make students enjoy in their reading comprehension activity. Students who enjoy reading and devote time for reading every day, they will do more effort to understand. Students who have motivation will try to focus and enjoy in comprehending a text.

Besides, Motivation gives main contribution in determining students' success. Brown (2000, p. 160) stated 
that success in task is due simply to the fact that someone is motivated. Besides, Brown (2000, p. 160) also stated that a student will be successful with the proper motivation. It explains clearly that motivation is very crucial in learning process, especially in reading comprehension activity. In addition, Rahim (2007, p. 1) stated that children who doesn't understand about the important of reading comprehension will never be motivated to learn something. It means that before reading something, we will be motivated in reading if we know and realize that reading is important. Besides, Iskandarwassid et al. (2008, cited in Kaharu, p. 2) stated that reading comprehension would be more effectively if it is being supported by motivation. In this case, from these views, it can be concluded reading comprehension will be supported by motivation

Based on the explanation above, the objective of the research was to find out how big is the female students' motivation in comprehending narrative text at the first year of State Vocational High School 1 Pekanbaru.

\section{Reseach Method}

The design of this research is descriptive quantitative research. Descriptive research is also called as survey research that collected numerical data to answer question about the correct status of the subject of the study. According to Gay (2012, p. 183) stated that descriptive research is a survey research. This research are involves collecting data in order to test hypotheses or to answer questions about the opinions of people about some topic or issue. Besides, Creswell (2012, p. 376) stated that survey research designs are procedures in quantitative research in which investigators administer a survey to a sample or to the entire population of people to describe the attitudes, opinions, behaviors, or characteristics of the population. And descriptive research is concerned with how what is or what exists is related to some preceding event that has influenced or affected a present condition or event (Best, 1970 cited in Cohen, 2000, p. 169).

This research was conducted at State Vocational High School 1 Pekanbaru on April - May 2018. The population of this research is the female students in Office Management Major at the tenth grade of State Senior High School 1 Pekanbaru. The total of the population is 107 students which are divided into three classes. Then, the sample of this research was 33 students. Creswell (2012, p. 142) stated that sample is a subgroup of the target population that the researcher plans to study for generalizing about the target population. In an ideal situation, we can select a sample of individuals who are representative of the entire population.

This research used Purposive sampling as the technique to choose the sample of population. Sugiyono (2014, p. 122) stated that purposive sampling is a sampling technique where the researcher take into a certain consideration in deciding the sample.

The desired sample in this research is 33 students. The researcher 
took 33 students as the sample because the total population of this research was more than 100 students. Arikunto (2006, p. 112) stated that if the population is more than 100 , the researcher should take the sample in the range of $10-15 \%, 20-25 \%$, or more. That is why the researcher took $30 \%$ students (33 students) as the sample of the total population (107 students).

The subject in the research is female students in Office Management major the tenth grade students of State Vocational High School 1 Pekanbaru. Furthermore, the object of the research is the female students' motivation in comprehending Narrative text.

The indicators of students' motivation in Reading comprehension of Narrative text are developed based on Watkins and Coffey, 2004; Suwardati, 2006:

1) Grade-compliance refers to the students have feeling that they have to do their reading work and they need to increase their level in reading.

2) Involvement refers to the students have feeling engagement between the readers and their reading text.

3) Social refers to the students have social reason for reading.

4) Competition refers to the students push themselves to be a better reader than other readers.

5) Reading work avoidance refers to the students think and identify why sometimes they avoid reading.

6) Curiosity refers to the students have curiosity or to be curious for what they read.
7) Recognition refers to the students have feeling they need recognition or to be recognized as a good reader or not.

8) Efficacy refers to the students knew their reading ability and they believe that they have better ability in reading than any other materials.

9) Orientation refers to the students can identify the orientation part of Narrative text.

10) Complication refers to the students can identify the complication part of Narrative text.

11) Resolution refers to the students can identify the resolution part of Narrative text.

\section{Technique of Collecting Data}

In this research, the researcher used a set of questionnaire to collect the data of students' motivation in reading comprehension of Narrative text. There were twenty two items of questionnaire which were developed based on eleven indicators of motivation reading comprehension of Narrative text by Watkins and Coffey (2004) and Suwardati (2006); grade-compliance, involvement, social, competition, reading work avoidance, curiosity, recognition, efficacy, orientation, complication, and resolution. Questionnaire is one of the types of self-report instruments, it consists of a number of questions should be answered by respondent about their actions and beliefs (Schunk, 2008, p 21). The questionnaire deal with respondent's opinions in responding to following options based on the rating scale. Schunck et al., (2008, p. 19) 
stated that motivation can be measured by using questionnaire.

In a rating scale, the individual is asked to rate performance or preference using a numerical scale similar by Watkins and Coffey (2004); a lot like me, a little like me, a little different from me, very different from me. For positive statements, the answer "a lot like me" the score was 4, answer "a little like me" the score was 3, answer "a little different from me" the score was 2, and answer "very different from me" the score was 1. For negative statements, the answer "a lot like me" the score was 1, answer "a little like me" the score was 2, answer "a little different from me" the score was 3, and answer "very different from me" the score was 4 .

Before distributing the questionnaire, the researcher firstly measured the validity and reliability of the questionnaire by trying out once. The writer used construct validity and the data obtained was calculated by SPSS 21.0 Windows program. Siregar (2013) stated that the item of questionnaire is valid if the value of $r$ observed is higher than $r$ table at significance level of $5 \%$. Moreover, to see the reliability of the questionnaire, the writer used internal consistency in which the writer tried out the questionnaire once and analysed each item by using cronbach's alpha technique. Jogiyanto (2008, p. 143) Cronbach' alpha was used to measure the reliability if the survey questionnaire tool.

\section{Technique of Analyzing Data}

The technique of analyzing data in this research was Percentage Formula by Sudijono (2004, p. 43). The technique was used because the researcher wanted to know the average of the percentage of female students' motivation in reading comprehension of Narrative text.

\section{Research Findings}

The result of students' motivation in learning English can be seen in the following table:

\begin{tabular}{|c|c|c|c|c|}
\hline \multirow{2}{*}{ No } & \multicolumn{4}{|c|}{ Score } \\
\cline { 2 - 5 } & $\mathbf{4}$ & $\mathbf{3}$ & $\mathbf{2}$ & $\mathbf{1}$ \\
\hline $\mathbf{1}$ & 5 & 19 & 9 & 0 \\
\hline $\mathbf{2}$ & 7 & 12 & 13 & 1 \\
\hline $\mathbf{3}$ & 4 & 14 & 13 & 2 \\
\hline $\mathbf{4}$ & 4 & 12 & 14 & 3 \\
\hline $\mathbf{5}$ & 5 & 16 & 10 & 2 \\
\hline $\mathbf{6}$ & 5 & 12 & 15 & 1 \\
\hline $\mathbf{7}$ & 5 & 10 & 16 & 2 \\
\hline $\mathbf{8}$ & 3 & 13 & 10 & 7 \\
\hline $\mathbf{9}$ & 2 & 16 & 15 & 0 \\
\hline $\mathbf{1 0}$ & 8 & 8 & 13 & 4 \\
\hline $\mathbf{1 1}$ & 5 & 21 & 6 & 1 \\
\hline $\mathbf{1 2}$ & 5 & 15 & 13 & 0 \\
\hline $\mathbf{1 3}$ & 3 & 16 & 13 & 1 \\
\hline $\mathbf{1 4}$ & 9 & 14 & 10 & 0 \\
\hline $\mathbf{1 5}$ & 11 & 9 & 9 & 4 \\
\hline $\mathbf{1 6}$ & 11 & 10 & 5 & 7 \\
\hline $\mathbf{1 7}$ & 5 & 7 & 12 & 9 \\
\hline $\mathbf{1 8}$ & 5 & 7 & 13 & 8 \\
\hline $\mathbf{1 9}$ & 4 & 8 & 14 & 7 \\
\hline $\mathbf{2 0}$ & 3 & 9 & 14 & 7 \\
\hline $\mathbf{2 1}$ & 2 & 9 & 13 & 9 \\
\hline $\mathbf{2 2}$ & 4 & 8 & 12 & 9 \\
\hline Ttl & 115 & 265 & 262 & 84 \\
\hline & & & & \\
\hline
\end{tabular}


From that table, it can be seen that from twenty two questionnaires of students' motivation in reading comprehension of Narrative text which have been answered by thirty three students, the total frequency of a lot like me was 115 , a little like me was 265 , a little different from me was 262, and very different from me was 84 .

In order to get the average of the percentage of female students' reading motivation, the researcher summed the total score of each alternative. Sugiyono (2012, p. 137) stated that obtained total frequency from each score was multiplied by standard-score from each alternative.

The result acquired can be seen as follows:

1. For Positive Statement:

Total frequency of a lot like me:

$104 \times 4=416$

Total frequency of a little like me:

$244 \times 3=732$

Total frequency of a little different from me:

$239 \times 2=478$

Total frequency of very different from me:

$73 \times 1=\frac{73}{1699}+$

2. For Negative Statement:

Total frequency of a lot like me:

$11 \times \quad 4=44$

Total frequency of a little like me:

$23 \times 3=69$

Total frequency of a little different from me:

$21 \times 2=42$

Total frequency of very different from me:
11

$\mathrm{x} \quad 1=\frac{11}{166}+$

The ideal score of the whole items should be 4 × 22 × $33=2904$ (if all respondents answer always for each item of questionnaire). However, the total score acquired was $1699+166=$ 1865. Based on the data, the percentage of the research can be analysed as follows:

$\mathrm{P}=\frac{F}{N} \times 100 \%$

$\mathrm{P}=\frac{1865}{2904} \times 100 \%$

$\mathrm{P}=64.2 \%$

The percentage of students' motivation in learning English was 64.2 $\%$. Riduwan (2011, p. 23) stated that the percentage of questionnaire in the range of $61 \%-80 \%$ is categorized into high level. It could be concluded that female students' motivation in reading comprehension of Narrative text at the first year of State Vocational High School 1 Pekanbaru was high because the percentage obtained was $64.2 \%$.

\section{Conclusion and Suggestion}

Based on the data presentation and data analysis which had been describes in previous chapter, it can be seen that the average score of female students' motivation in comprehending narrative text at the first year of State Vocational High School 1 Pekanbaru was $64.2 \%$ and categorized into high level.

Finally, from the explanation above it can be concluded that most of female students at the first year of State Vocational High School 1 Pekanbaru have high motivation in reading comprehension of narrative text. 
Based on the research findings and conclusion, it is known that female students' motivation in reading comprehension of narrative text is high. Certainly, the researcher would like to give some suggestions:

The first suggestion is for the female students, they are expected to increase their reading motivation. All of the female students must be aware that English is very important especially for their carrier in the future. From the data presentation and data analysis, it could be seen that there were some of the female students who had average level of reading motivation. It means that if those female students increase their reading motivation, they will have higher motivation than they have yesterday, and they will get good comprehension in reading comprehension activity of narrative text.

The second is for English teachers as one of the main points in supporting students in increasing their motivation in reading comprehension. They have to concern more on how to motivate their students. They have to try to motivate their students by giving interesting situation in the classroom. They also should try to give some learning activities that can make students enjoy the learning process, such as by using some new interesting media or learning method which give students a chance to practice their reading comprehension skill actively. If the English teachers can build and increase their students' reading motivation and give a chance to the students to practice their reading comprehension skill actively, the students will be motivated to read and get good comprehension in reading comprehension activity .

Finally, for the other researchers who want to conduct a similar research, this research can be used as a source of reference to support their researches..

\section{References}

Amelia, Rizki. (2016). Second Language Acquisiton. Pekanbaru: Cahaya Firdaus.

Arikunto, S. (2006). Prosedur Penelitian Suatu Pendekatan Praktik. Jakarta: Rineka Cipta.

Brown, H. Douglas. (2000). Principles of Language Learning and Teaching (Fourth Edition). New York: Pearson Education.

Cohen, Louis., Lawrence Manion, and keith Morrison. (2000). Research Method in Education (Fifth Edition). London: RoutledgeFalmer.

Creswell, John. W. (2012). Educational research: planning, conducting, and evaluating qualitative research: Fourth Edition. New Jersey: Pearson Education.

Erman, E. (2013). The Correlation between Students' Reading Motivation and Students' Reading Comprehension. 4, 9.

Gay, L. R., Geoffrey E. Mills, and Peter Airisan. (2012). Educational Research: Competencies for Analysis and Application. New 
Jersey: Pearson Education.

Indrawati, Sri Ni Putu. (2014). The Implementation of Intensive Reading to Improve Reading Comprehension of the Seventh Grade Students of SMPN 4 Denpasar in the Academic Year 2013/2014. Bali: Universitas Mahasaraswati Denpasar.

Jogiyanto. (2008). Metodologi Penelitian. Yogyakarta: Penerbit Andi.

Kaharu, Dwi Oktavia Nur. (2012). The Correlation between Students' Motivation and Reading Comprehension in Reading English Text. Gorontalo: Universitas Negeri Gorontalo.

Kementrian Pendidikan dan Kebudayaan. (2013). Kompetensi Dasar: Sekolah Menengah Atas (SMA) / Madrasah Aliyah (MA). Jakarta: Badan Standar Nasional Pendidikan.

Mead, Megan. (2012). Reading Motivation: The Different between Boys and Girls and their Reading Preference. New York: Fisher Digital Publications.

Rahim, Farida. (2007). Pengajaran Membaca di Sekolah Dasar. Jakarta: Bumi Aksara.

Riduwan. (2014). Metode dan Teknik Menyusun Tesis. Bandung: Alfabeta.

Sardiman, A, M. (2007). Interaksi \& motivasi belajar mengajar. Jakarta: Rajawali

Pers.

Siregar, Sofyan. (2014). Statistik Parametrik untuk Penelitian Kuantitatif. Jakarta: Bumi Aksara.

Schunk, Dale H., Paul R. Pintrich, and Judith L. Meece. (2008). Motivasi Dalam Pendidikan. Jakarta: Indeks.

Sudarwati, Th. $\mathrm{M}$ and Eudia Grace. (2006). Look Ahead 1. Jakarta: Erlangga.

Sudijono, Anas. (2004). Pengantar Statistik Pendidikan. Jakarta: Raja Grafindo.

Sugiyono. (2012). Metode Penelitian Pendidikan. Bandung: Alfabeta.

Sugiyono. (2014). Metode Penelitian Bisnis. Bandung: Alfabeta.

Watkins, Marley W. and Debra Young Coffey. (2004). Reading Motivation: Multidimesional and Indeterminate. Journal of Educational Psychology, Vol. 96, No.1, 110, 114-116. (Retrieved on January $23^{\text {th }}$, 2018). 
Shelly Septiani, Jasno Susanto - An Analysis on Female Student's Motivation ... 